\title{
Evaluating the Relationship between the Banking System Stability and the Internal Capital Adequacy Assessment Process: Evidence from the Egyptian Banking Sector
}

\author{
Karim F. F. Mohamed \\ Ecole Supérieure Libre des Sciences Commerciales Appliquéesis, Prais, France \\ Email: karim.f.f.mohamed@gmail.com
}

How to cite this paper: Mohamed, K. F. F. (2018). Evaluating the Relationship between the Banking System Stability and the Internal Capital Adequacy Assessment Process: Evidence from the Egyptian Banking Sector. Journal of Financial Risk Management, 7, 331-368.

https://doi.org/10.4236/jfrm.2018.74020

Received: October 3, 2018

Accepted: November 12, 2018

Published: November 15, 2018

Copyright $\odot 2018$ by author and Scientific Research Publishing Inc. This work is licensed under the Creative Commons Attribution International License (CC BY 4.0)

http://creativecommons.org/licenses/by/4.0/

\begin{abstract}
In the repercussions of the latest financial crisis that have occurred on the years 2008-2009, to fortify the stability of the banking systems, policy makers, and the Basel Committee on Banking Supervision-BCBS, together with national regulators have built up a few safety measures, and structures to guarantee that banks establishments keep up adequate capital levels through using risk management tools, in specific the Internal Capital Adequacy Assessment Processes (ICAAP). They all have called for thorough evaluations and assessments for the structure and components of risk management frameworks, tools, and practices whether by banks, regulators, analysts and risk management experts consistently, to ascertain the adequacy of the banking systems, policies, arrangements and techniques for overseeing risks, and guaranteeing the sufficiency of holding appropriate capital levels for confronting normal, as well as adverse and unexpected situations or emergencies. The main objectives of this research study are to shed the light on the ICAAP as one of the main keys of risk management programs, a process by which banks can use to ensure that they operate with an appropriate level of capital, forward looking processes for capital planning covering a broad range of risks across banks, activities beyond simple capital management, and bring together risk and capital management activities in a form that can be used to support business decisions. The research study shall evaluate the significant relationship between the Banking System Stability (dependent variable) and the Internal Capital Adequacy Assessment Process (ICAAP_independent variable) with evidence from the Egyptian Banking Sector.
\end{abstract}

\section{Keywords}

Financial Crisis, Banking System Stability, Internal Capital Adequacy 
Assessment Process, Risk Weighted Assets, Emerging Markets

\section{Introduction}

The previous decade has seen a standout amongst the most catastrophic financial crises. The impacts of the latest financial crises were inescapable and hit mostly every segment of the worldwide organizations; the most influenced sector was particularly the banking sector which represents a corner stone for the worldwide financial stability and achieving a solid economic growth. The banking sector did not only experience and face the dramatic failures. In fact disappearance of several well known financial organizations like Leman Brothers, it has likewise turned into a standard focus for harder directions, tougher regulations, open outrage, and academic criticism (Laeven \& Valencia, 2010). There were various clarifications for the reasons of the named financial crisis. One factor that has gotten huge consideration amid this crisis is risk management discourse. Therefore, risk management has turned out to be such an essential and central indispensable instrument, from which banks have begun to completely use, not exclusively to accomplish the best possible authenticity levels towards the general public and regulators, yet in addition for adequately achieving banks objectives according to the set standards of risk appetite and thresholds.

Egyptian Banking Triggers:

On the basics that the failures confronted by the worldwide banking industry, during the latest financial crises in 2008-2009, have been contemplated to a great extent on mainly the shortcomings of the national regulator's frameworks, structures and the risk management methodologies across the financial organizations, this triggering impact has given stakeholders in the Egyptian banking sector cause not exclusively to consider the profits made in the sector, yet additionally and basically analyze structures used to oversee risks and save their interests.

Although the consequences of the 2008-2009 latest global financial meltdown have been quite minimal on the Egyptian banking sector that did not threaten the existence of banks working in Egypt, yet it has served as an early warning signal to all banks. This is reasoned that the Egyptian market banks, basically, depend on low cost domestic deposits mainly for liquidity purposes, which is completely different than the situation at developed countries, where named market banks depend on complex financial instruments that represented one of the main causes of the financial crises. However, during the fiscal year 2008-2009, the performance of the Egyptian economy was normally affected by the global financial crisis and its consequences that had reached its upmost during the first quarter for the year 2009, but began to recover back starting from June with a modest growth pickup (CBE 2008, 2009c). One of the main faced impacts was the dipping down of the real GDP growth rate from $7.2 \%$ to $4.7 \%$ a year earlier. 
Despite the adverse effects of the crisis on the Egyptian economy, some positive signs were witnessed backed by the proper and effective risk management initiatives that were implemented during the banking reform phase, such as: the decrease in annual inflation rate reaching $9.9 \%$ in June 2009 , down from $20.2 \%$ on June 2008, in addition to the GDP increase to reach EGP 1 trillion (CBE 2008, 2009c).

Egypt's commercial banking sector was undergoing a long term process of consolidation, privatization and recapitalization (BMI, 2016). According to the Central Bank of Egypt (CBE), there were 39 licensed banks at the end of the year 2016. Traditionally, the sector has been dominated by the "big four" public sector banks: National Bank of Egypt (NBE), Banque Misr, Banque du Caire and, until its privatization in 2006 Bank of Alexandria. According to BMI's analysis, the segmentation of the banking sector in Egypt is segregated across 3 main classes: Public sector banks which included the same previously mentioned domination banks-excluding Bank of Alexandria-in addition to Egypt Arab Land Bank and Principal Bank for Development and Agricultural Credit. The second list included the vast majority of the market's bank names (27 banks) which represented private and joint venture banks, holding an approximate of $70 \%$ of the commercial banking sector names in Egypt, and ending with branches of foreign banks, e.g. First Abu Dhabi Bank (formerly named National Bank of Abu Dhabi) and Mashreq Bank.

At the same time, the national regulator under the name of the Central Bank of Egypt (CBE) has started managing the banking reform activities in 2004 (CBE, 2004) with the purpose of restructuring the banking sector. A restructuring design was created with the goal of strengthening the banking sector and expanding its robustness to enable it to face global and regional competition effectively, and by turn to focus on the targeted economic growth and development. The plan has begun in 2004 and finished in 2008 involving: Privatization and consolidation within the banking sector, addressing the issue of none performing loans (NPLs), financial and managerial restructuring of state owned banks, and upgrading CBE banking supervision infrastructure.

The industry, however, has lately witnessed a worsening trend for banks capital adequacy ratios due to the Egyptian currency free float (CBE, 2016d), which has decreased from $12.1 \%$ for common equity as being compared to risk weighted assets in December 2015 to reach 9\% at December 2016 which represented a 26\% decrease (CBE 2016d, 2017b); by turn the considerable increase in the value of foreign currency assets based on this decision. The local currency devaluation decision has negatively impacted assets quality of banks as a result of the deteriorating country economic factors like depreciating local currency, increasing trends of inflation and default rates.

\subsection{Statement of the Research Study Problem}

Considering the limited findings with regard to the evaluation of the relationship between the Banking System Stability and the Internal Capital Adequacy 
Assessment Process-ICAAP, besides the low consideration of the previous few studies on emerging markets, like Egypt, but focusing on the developed countries; this research study is necessary to present empirical robust results in order to fill this gap and provide the adequate evidence in terms of assessing the significant relationship (if any) between the Banking System Stability and the Internal Capital Adequacy Assessment Process.

\subsection{Importance of the Research Study}

The relationship between the developments of a nation's banking industry and its economic growth has been examined comprehensively. However, few research studies and investigations have attempted to clarify how the connection between the banking system stability development/improvement and the economic growth works amid times of financial shakiness. Bauducco, Bulir, and Cihak (2008), Hakkio and Keeton (2009) and Carlson et al. (2009) have analyzed the impacts of financial stress on economic performance. They have called attention that there is significant relationship between the banking and financial stability, and the economic growth. They have concluded that there are three distinct channels of which the banking and financial instability can adversely influence the economic growth. The first channel is an uncertainty increase with respect to the fundamental value of assets and the investors' behavior during periods of financial instability. Since these two sources of instability are frequently followed by increases in the volatility of asset prices, this condition makes banking organizations more cautious about investment choices and decisions until the point when the vulnerability vanishes. Likewise, households sector tend to decrease their spending in the midst of financial shakiness, since the uncertainty influences the normal estimation of their future wealth. As an outcome of these said responses, a fall in the economic output begins to be displayed.

The second route is through the decrease trend for borrowing conditions reasoned of tight credit lending standards by banks (Lown et al., 2000). At the point when banks increase their base credit norms it winds up noticeably harder for borrowers in terms of funding receive, trailed by a resulting negative impact on the economic growth and slowdown.

From an alternate point of view, the financial shakiness can prompt an abating of the economic development through an increase in the cost of firms and households of fund spending. Hakkio and Keeton (2009) have noticed that instability expands financing costs on business and individual obligations at the capital markets, truing to be more costly for firms to raise finance. Such an increase in the cost of funding can make firms and families cut back on their spending and unfavorably influence the financial and economic cycles and development in general.

William C. Dudley, President and Chief Executive Officer of the Federal Reserve Bank of New York, has remarked on September 2011 that a stable banking system is a prerequisite for sustainable economic growth. He added that the financial system that has operated within the financial crisis period had generated 
terrible outcomes in terms of economic growth and unemployment, returns available to savers and access to credit for borrowers (Dudley, 2011).

\subsection{Objectives of the Research Study}

The global financial crisis has brought a new scenario within the banking sector, showing regulators implementing new risk management tools, the ICAAP in specific, to monitor the strength of banks hence, enhance the banking system stability through incorporating effective risk management systems and tools to be aligned with the banking sector's best-in-practice.

Previous studies and examinations have mentioned diverse aspects of banking and financial stability, the different sorts of sensitivity tests and stress test scenarios (Ingo, Michael, \& Mosser, 2001), and also the choice of the sever but plausible situations to use in the stress testing exercise following the recommendation of the Bank for International Settlements-BIS (Alfaro and Drechman et al., 2010). Therefore, the general objective of this research study is to:

- Support in terms of forward-looking processes for capital planning for banks, that includes the linkage of all quantitative and qualitative parts, and possible adverse and stressed scenarios that maybe be faced, to be fully interlinked with the banks strategies, business decision making and risk management processes (internal reporting, limit system, risk appetite framework, etc.).

- Set the proper and effective ways of the ICAAP and its impacts on: assessing the capital ratios, study and assess banks' frameworks of capital planning over medium to long terms, determine the accurate capital adequacy ratios needed to support strategies/plans/objectives for banks businesses during the mentioned time intervals, and by turn issue a sustainability report disclosing relevant information and recommendations or corrective action plans to react proactively towards any deviations from the level of required capital, whether this capital represents the regulatory capital, as can be seen at Figure 1 , according to the national regulator's statement, i.e. CBE. Figure 1 shows the economic - capital including additional buffers (shock absorber) — which are mainly utilized for absorbing any expected crises without affecting the financial stability of the bank or its competency level within the market(s) it is functioning within, ending with the positive impact on its reputation. Therefore, these excess over regulatory capital requirements as buffers makes a trade-off between capital prerequisites and the cost of supervision that banks holds over the minimum capital prerequisite keeping in mind the end goal to bring down the risk during economic and financial turmoil periods.

- The research study and examination shall also represent a helpful guide to: Policy formulations either by the government of Egypt, The Central Bank of Egypt (CBE), Union of Arab Banks (UAB), Egyptian/Arab/African/Emerging Market Zone Banks, and also for investors and strategy producers. It will enable them to make suitable arrangements with respect to the foundation of a more stable banking organizations through the usage of the Internal Capital 


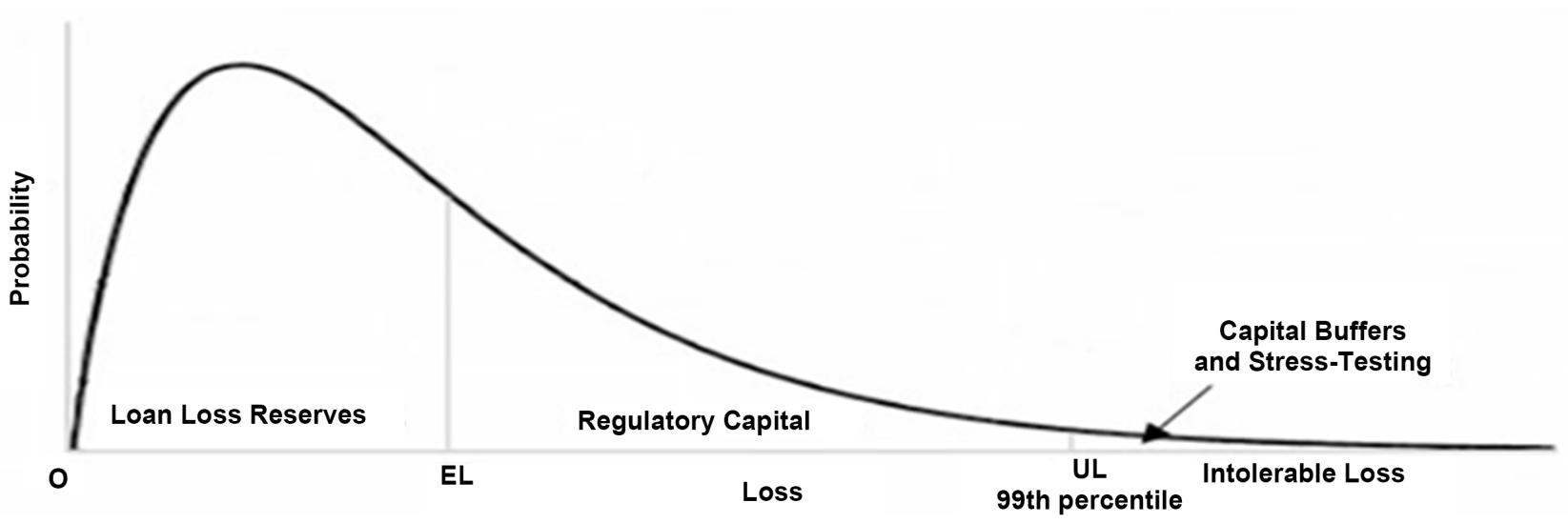

Figure 1. Bank credit loss distribution. Source Durrani (2013).

Adequacy Assessment Process application (ICAAP), and how the existing banks can be urged to extend, advance growth, mobilize funds, viable face shocks, and designated resources proficiently with strong and well forecasted gauge plans bolstered by adequate capital levels.

For the purpose of solving the research problems and getting the outcomes of the research study objectives, the study aims that will be investigated are as follows:

- How can the ICAAP be used to limit or promote risk taking activities in order to ensure the continuing financial strength of the bank, and the fulfillment of the regulatory requirements?

- How can the ICAAP projection methods be utilized to challenge banks business plans and budgets?

- Is it possible to use the ICAAP for effective banks' planning with regard to assets and liability allocations, stable growth, and ensuring that the risk taking activities of any bank do not exceed its risk capacity and capital required levels?

- How can the ICAAP be utilized to adjust the gap between the current and the targeted risk levels of the banks capital structures?

\subsection{Research Study Hypothesis}

Research Hypothesis:

H0: There is no significant relationship between the Banking System Stability and the Internal Capital Adequacy Assessment Process (ICAAP).

H1: There is a significant relationship between the Banking System Stability and the Internal Capital Adequacy Assessment Process (ICAAP).

Research Question:

What is the relationship (if any) between the Banking System Stability and the Internal Capital Adequacy Assessment Process (ICAAP)?

\subsection{Limitations of the Research Study}

There are several limitations in this research study that should be taken into 
consideration in future researches. The research sample is small and limited to the selected research study banks ( 5 banks). This is due to the difficulty faced in terms of data access and confidentiality reasons across the banking sector, Egyptian banking sector in specific, especially for the data that shall be utilized under the internal capital adequacy assessment process (ICAAP), of which the researcher has suffered a lot to obtain the required data for the research study. Therefore, the sample was only limited to those banks that are included in. This has prevented the researcher from widening the sample across more study banks and risk measures.

To overcome this confidentiality obstacle, the research study depended on secondary published data. This was acquired from the annual reports and financial statements, besides historical financial reports for the main study year (December 2016), in addition to different reports issued by research associations (e.g. BMI, and Macropolis), and statistical reports published by several national regulators (e.g. SAMA, and CBE).

Moreover, and to overcoming named research study limitations; it is worth to be mentioned that there is no significant difference between the selected research study Egyptian banks-structures and operations-as being compared with the other Egyptian banks in terms of: Products bouquet, pricing, market penetration, functional structure, reliance mainly on low cost domestic deposits and liquidity rather than exposure to complex financial instruments, and facing the same market economic conditions during the under study period, i.e. post the EGP free float and effects on capital ratio levels. All ends up with the close similarity between different Egyptian banks for the same mentioned factors within the selected study period. That shall smooth down, considerably, the research study limitations.

For the selected sample banks, the ICAAP was utilized for reaching a sound capital management to identify, measure, and report all material risks, taking into account the banks' strategic focus and business plans, although the annual reports and financials did not mention the ICAAP in focus terms (due to the same confidentiality reasons), still the process of internal controls, reviews and analysis included is showing clearly the ICAAP assessment, findings, and implemented corrective action plans following the Supervisory Review Process (SRP) for the Central Bank of Egypt (CBE), as well as Basel rules under pillar 2.

Consequently, the presented research study shall focus on the: Commercial International Bank (CIB), Credit Agricole Egypt (CAE), the Union National Bank Egypt (UNBE), all as practical case studies, and based on the assessment of their risk profiles and financials status for the research study period. The goal is to expand and generalize the ICAAP model implementation across the banking sector, whether in Egypt, or the emerging markets, in general; to check how the ICAAP shall ensure and enhance the financial stability of banks. It is worth to be mentioned that 1 international and 1 regional bank (MENAP) were identified and presented to show the ICAAP impacts on capital planning, forward looking approach and financial stability. The first is HSBC-UK, and the second is Samba 
Financial Group, The kingdom of Saudi Arabia.

The research study shall be organized as follows:

- Section 2: Literature Review.

- Section 3: Research data and Methodology.

- Section 4: Data Studies and Results.

- Section 5: Conclusions.

\section{Literature Review}

\subsection{Introduction}

The latest global financial crises have gotten out the questions as to the financial related markets stakeholders' level of understanding on financial institutions' risks and complexities. The economic slowdown, which started earlier in the year 2008, brought about the crash of some financial organizations that prompted the need for the improvement of new systems and rules within the banking sector. The European Banking Authority (EBA) has led an examination in 2012 to see how banks measure the assets riskiness, of which the named research has demonstrated that banks are excessively shrewd for controllers. The EBA presumed that there were "material contrasts" in the way risks are measured over the directed investigation test which included 89 banks in 16 nations. The chairman of EBA, Andrea Enria (The Guardian, 2013) has noted that a portion of the variations could be represented by more clarification about the methodology being utilized, yet this is insufficient. The rest of the scattering is noteworthy and calls for additional examinations and perhaps policy solutions, he added.

To enhance the world's financial stability, the initial mandate was given to the Financial Stability Board which was established by a forum including the Finance Ministers and Central Bank Governors of the Group of Seven (FSB, 1999).

The financial Stability Board has issued its analysis (FSB, 2009), submitted to the G20 for "Improving Financial Regulation" through a more disciplined, stable and less procyclical financial system that effectively bolsters a balanced sustainable economic growth, which is supporting William Dudley's view (Dudley, 2011). Recommendations have stated that the higher requirements of substantially needs, effective quantity and quality of capital and liquidity levels at banks represent an asset towards financial stability, as the banks targets as far as overseeing capital are: To follow the capital necessities set by the national regulators and as per nation rules, to protect the banks capacity to proceed as a going concern so it can keep on providing returns for investors and benefits for shareholders, keeping up a solid capital base to help the development of its business, and completion with the positive effect on the economic growth in general.

The same report (FSB, 2009) has also included reforms to accounting standards and compensation regimes that improve transparency, limit incentives to excessive risk taking, proper capital planning through utilizing risk management 
tools (e.g. ICAAP), constrain risks in trading related activities by improving market infrastructure and by significantly raising capital charges for reasonable capital planning and forward looking visions.

\subsection{Banks and Capital Requirements}

The banking business is highly regulated due to the fact that deposits receiving financial institutions receive open reserve funds and have particular risks and complexities that put forth their financial statements obscure and hard to be analyzed for the general public audience (Ingo, Michael, and Mosser, 2001). In this way, it is hard to comprehend that in a segment with such strict regulatory conditions, nothing should be impossible to anticipate and save from the last happened worldwide financial crisis. The attributes that make banks unique in relation to other sort of financial organizations were the reasons for their collapse.

To comprehend and screen the particular risks in the financial sector organizations, the US regulator has designed the "CAMELS" rating framework (FRB, 2016), which is usually utilized by regulators worldwide to survey the quality of banks and to assess the level of banks risks. The risks that this approach assesses are the particular risks of all banks, such as: capital risk, assets quality, management skills, earning and profitability, liquidity risk and sensitivity to market risk.

The CAMELS approach is utilized as a part of the US, as well as the different regulators across the globe. One case is the supervisory strategy utilized by the Banco de España (the Spanish regulator) and the Central Bank of Egypt (CBE) which is called Risk-Based Supervisory Methodology approach and it depends on the CAMELS rating framework.

This strategy supports in terms of evaluating which banks will probably face issues later on, so as to devote extra supervisory resource, avoid future crises (Banco de España, 2011; CBE, 2016b), and support the sustainable economic growth through financial stability levels.

Therefore, risk management tools has turned to be the essential and central indispensable instrument, from which all banks have begun to completely use, not exclusively to accomplish the best possible authenticity levels towards the general public and regulators, yet in addition for adequately achieving banks objectives according to the set standards of risk appetite and thresholds. Besides, national regulators have tuned to empower banks to utilize other refined risk management tools, other than the CAMELS model which is mainly utilized on a top down approach from a regulator's perspective, such as the ICAAP as an internal and essential application for banks to affirm that they execute their strategies and business plans based on a guaranteed and well assessed adequate capital levels consistently, with due thoughtfulness regarding every single material risk. Following the same, the ICAAP key attributes as being represented as a bottom up approach are: Possess risk capital which is commensurate with their selected risk profile and risk appetite, develop appropriate governance and control functions and business strategies to safely and effectively face those risks. 
Setting an ideal capital requirement represents one of the desires of every financial services regulator since it will help them to conform to their command of keeping financial stability. Banks finance themselves with households and business deposits, in addition with equity capital that, by turn, use to put resources into risky assets (Allen et al., 2014). Deposit investors assume a disciplinary action(s) with bank's management in light of the fact that on the off chance that they suspect that management is wasteful they can pull back their deposits leading to the bank's bankruptcy (Calomiris \& Kahn, 1991). The capital structure theory recommends that the ideal capital requirement ought to have two parts: a core capital requirement to restrain the bank leverage, and a capital supporting buffer (Archarya et al., 2014; Admati et al., 2013) unquestionably following the guidelines that are either set through the Basel Committee for Banking Supervision (BCBS 2010, 2011a) or the national banking regulators, for example, the Central Bank of Egypt (CBE 2009d, 2012b, 2016e).

Therefore, to address and screen the banking business risks, national regulators have turned to utilize risk management tools, ICAAP in particular, to accomplish financial strength. Such regulatory endeavors increment amid times of financial turmoil since bank mistiness tends to expand (Flannery et al., 2010) and subsequently, regulators have also utilized stress tests to assess the vulnerability of individual banks as well as of the whole banking system (Drehmann et al., 2010).

National regulatory bodies use to plan a supervisory framework that enable them to avert institutional failures that could end up with the breakdown of the main financial capacities in the economy, for example, the payment system, investment funds exchange, the monetary strategy and policy mechanism; as the principle worries of regulators is financial failures (Weber, 2014). Besides, and because of the way that banks are imperative for financial stability and strength, governments need to keep away from any failure, and to commit a lot of resources for banks saving. The liquidation of a bank has such a quick social cost on depositors in addition to several effects on different banks, for instance on the payment system, ending with the destabilize of the whole banking sector's management.

Mehran and Thakor (2009) have demonstrated that the higher the bank capital, the better for the bank, not just for the security of the banking system, yet in addition for the bank's financial strength itself. This is on the grounds that banks will screen borrowers; grow long term relationships with them which likewise create financial esteem and economic value. Allen et al. (2014) contended that banks need to hold a positive measure of equity capital as an approach to lessen bankruptcy cost when they finance risky investments. The basis behind this is when banks hold zero capital; their liquidation is lined up with those of firms on the grounds that there is no loans repayment to be exchanged to depositors. Then again, when bankruptcy costs are irrelevant, banks pick to fund themselves only with deposits. 
Equity holds higher required returns than debt since it is more risky, yet this does not really imply that the utilization of greater values in equity expands the funding cost of a bank (Admati et al., 2013). Actually, better promoted banks bring about lower costs when issuing additional capital and furthermore, as higher capital brings lower default risk standards, also it enhances the liquidity of debt securities that the bank issues.

\subsection{Capital Ratios and Buffering Levels}

Admati et al. (2013) had noticed that when the bank's capital ratio endures a decrease through losses or some other reasons, for example local currencies devaluation, the bank must recapitalize or deleverage, for example by selling assets. At the point when banks sell assets, they add pressure on assets markets across the economy and prices fall. To keep away from this, regulators increment capital requirements that will likewise infer the need of less help if there should be an occurrence of a bailout, also are continually looking for constant models to evaluate capital adequacy assessment systems to guarantee that banks are ceaselessly surveying and analyzing comprehensively their capital needs as indicated by their strategies for successful future looking perspectives.

Considering the high cost of capital, banks need to legitimize the span of the capital buffer they need to hold to ensure they do not run none compliance risk amid of a financial turmoil. Capital buffers are capital levels that banks hold in abundance of regulatory minimum capital requirements. Banks hold capital cradles to maintain a strategic distance from expensive intervention, to demonstrate to the market a sufficient financial position, to exploit good market openings and to create a cushion against recessions (Carvallo et al., 2016). On the off chance that banks do not aggregate capital buffers in the midst of financial blasts, consistence with regulatory minimum capital requirements could be troublesome during economic downturns, making it important to the bank to deleverage assets and narrow lending levels. This is on account of the cost of capital is higher when the bank is in a none compliance position.

Teixeira et al. (2013) have studied whether the determinants of banks capital structure is just dictated by regulations or by some other banks particular attributes. Utilizing an example of US and European banks for the period 2004-2010, the investigation has found that banks attributes influence their capital structure, to be more particular, the capital in abundance of the regulatory minimum or capital buffer. These findings have demonstrated that regulations do not represent the only determinants of banks capital structure and that banks hold capital cradles keeping in mind the main goal to maintain a strategic distance from the high cost related with issuing new equity capital at short notice. The findings have likewise featured that the macroeconomic factors as inflation, GDP growth, the stock market volatility and the term structure of interest rates additionally all affect banks capital structure.

Duygun et al. (2012) have studied the costs of recapitalization on an example of 22 Turkish banks for the period 2006-2009 that incorporates the last financial 
crisis. The investigation has incorporated banks particular qualities and macroeconomic factors. The outcomes demonstrated that the macroeconomic factors are not critical enough like banks particular attributes that catch the greater part of the applicable fluctuation in short run costs. The examination found also that the banks recapitalization that happened post the financial crisis period had expanded the costs significantly, driving the return on equity to negative levels. Considering these outcomes, Duygun has mentioned that there is a need to create recapitalization models, and the examination measured the effectiveness and profitability of the banks through the estimation of their cost function, where the equity capital is a fixed input requirement due to being regulated.

\subsection{Risk Management and Strengthening Capital Requirements}

Finding the optimal capital requirements is significant to keep the soundness of the banking system's stability and to be very much prepared for any negative impacts of an economic downturn. An approach to follow in concern is to evaluate the assets quality and risks properly through regulatory tools, such as Basel III risk weighting plans, and ICAAP (Archarya et al., 2014).

In this manner, the recent worldwide financial crisis has influenced it to clear that governments and regulators were not fully accomplishing the goals of observing banks to ensure they are beneficial to constitute a stable financial system. Banks managements had reached to the fact that they were not recognizing new risks and complexities in the business, and thus, they were not tending to addressing, mitigating, and alleviating them appropriately, holistically and comprehensively. Because of the same, financial services clients lost trust in banks in the wake of the crisis. In this new financial services segment situation, governments and regulators have discussed about the new regulatory risk management technique-ICAAP, which assist to highlight banks shortcomings in a timely manner. Banks need to fuse such tools as an integer component of their risk management frameworks to be lined up with their local regulators. This regulatory tool is not yet commonly utilized, particularly at developing markets, and this adds to the haziness of these markets.

Accordingly, setting an optimal capital requirement does not represent a simple assignment. Regulatory capital prerequisites typically utilize the book estimation of equity that relies upon the valuation of assets and liabilities which are represented utilizing particular accounting standards and risk-weighted assets (RWA) that follow the Basel rules. The justification behind risk-weighted assets is in accordance with the possibility that a superior capitalized bank will place assets into safer resources. Besides, regulators have tuned to utilize other refined risk management tools, for example the ICAAP, to affirm that banks should show that they have executed strategies and methods to guarantee capital adequacy ratios consistently, with due thoughtfulness regarding every single material risk and accomplish the key attributes of the ICAAP which include: to be a noteworthy piece of bank's management process and basic decision making culture, to be periodically examined, to be based on risks, to be extensive, having a 
future viewpoint, and to consider productivity of risk estimation and assessment process. The national regulator will then do the Supervisory Review Process (SRP) according to Basel's pillar II; to survey the soundness of the bank's ICAAP and the requirement for any actions (CBE, 2016e).

Jaime Caruana (2007) the Director of the IMF's Monetary and Capital Markets Department, had discussed the topic of strengthening the banking and financial stability and the role of banks in terms of achieving this objective by: increasing the soundness of their risk management systems to match the growing complexity of domestic and international financial markets, to help ensure that their actions do not have a negative impact on other participants in global financial markets, which is matching with the view of William C Dudley (Dudley, 2011), as well as Allen et al. (2014).

\subsection{Basel Committee on Banking Supervision and ICAAP}

The New Basel Capital Accord "International Convergence of Capital Measurements and Standards" (Basel III) has significantly affected the arrangement of keeping banking practices in the field of risk management considering the difficulties it has acquired at the banking activities.

The key target of the Basel II and III accords is to build up a revised framework that would additionally reinforce the soundness and strength of the worldwide banking system, to promote the adoption of more advanced risk management practices by the banking industry, and perspectives this as one of its significant advantages, all depends on three pillars that support the financial stability (Figure 2):

Pillar I-Minimum capital requirements: It establishes the measurement structure for the most imperative classes of risks which a bank must be confronted to: credit, market and operational risks.

Pillar II-Supervisory review process (SRP): It includes the stretched role by the national regulators in terms of assuring that banks operate with adequate capital using the ICAAP methodology, and that they apply internal processes to evaluate risks, take the necessary measures and actions when required. According to this pillar, each bank is obliged to create and an internal process used to calculate the minimum capital requirements in accordance with its own risk profile as an aim to assure that every bank holds adequate capital levels to raise early warning signals according to projection strategies and figures in case capital levels are falling below minimum standards, and by turn reach the financial stability across all banks and within the markets.

Banks are required to manage their own particular detailed Internal Capital Adequacy Assessment Process (ICAAP), to show that they have executed techniques, systems, and processes to guarantee satisfactory capital resources, with due consideration regarding all material hazards and hold adequate funding to cover extra risks outside of those risks characterized under pillar I (credit, market, and operational risks), such as liquidity, interest rate risk in the banking 


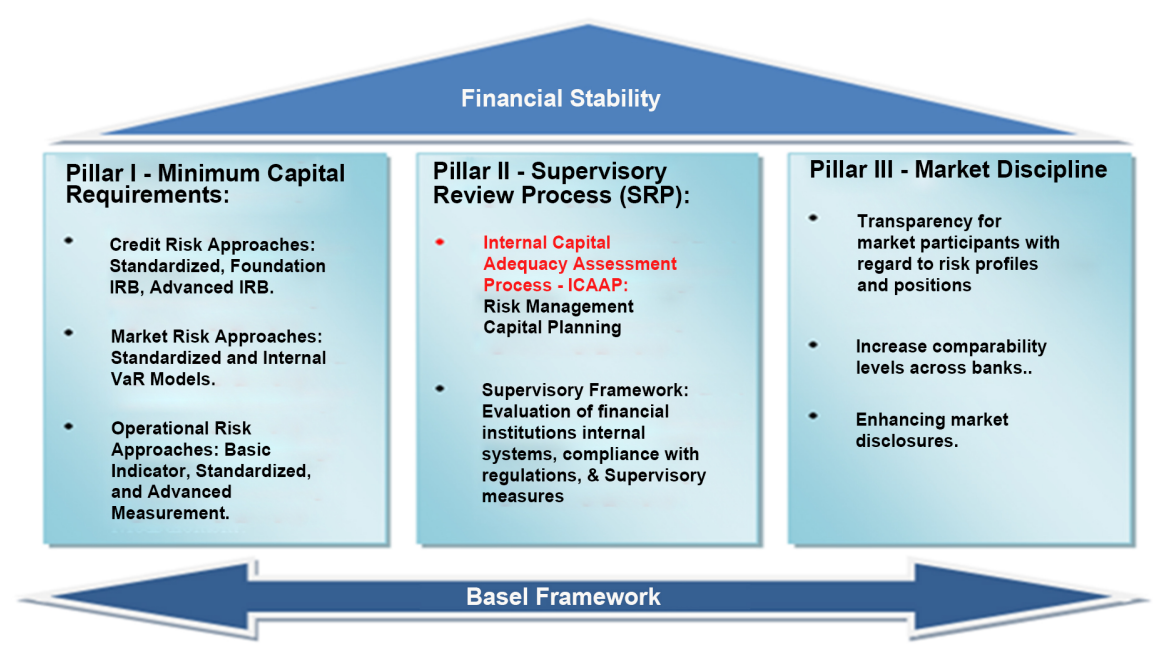

Figure 2. Basel pillars and spotting the ICAAP process and scope.

book, repetition risk, compliance risk, concentration risk, strategic risk, as well as other risks as per pillar II categorizations.

Effectively, Pillar II is the creation of a more extensive, adaptable and more risk sensitive framework which forces a noteworthy challenge on banks in meeting such necessities which comprehends the fundamental target of The Basel Committee on Banking Supervision (BCBS) for enhancing the financial stability and soundness (BCBS Charter). The ICAAP is an apparatus which guarantees that banks have risk capital which is matching towards their selected risk profile and risk appetite. This likewise expects banks to create a fitting governance, control techniques and business strategies. The ICAAP is gotten from a formal internal process, whereby banks evaluate their capital requirements in relation to their particular risk profile, strategy, business plan, governance structures, interior risk management frameworks, and so on.

Consequently, the national regulator (i.e. $\mathrm{CBE}$ ), will intervene at an early stage to prevent any bank's capital from falling below the minimum levels required to support the risk characteristics of a particular bank and will require a quick remedial action(s) if capital is not adequately maintained through the ICAAP results. All of which add value in terms of proper, effective, and comprehensive capital assessment, forward looking capital projections in light of risks faced/potentially will face within the financial projections and budgeting, and place the appropriate capital levels, beforehand, in cognizant with the bank's strategy and objectives.

Pillar III Market discipline: It enhances the market discipline through effective open public disclosure to supplement requirement necessities for Pillar I and Pillar II. Pillar III has presented substantial new public disclosure requirements necessities, which represent a significant increase in the amount of information made freely accessible by banks to the public with regard to the capital structure, capital adequacy, and risk management measures and tools.

Based on the previous illustration; The Internal Capital Adequacy Process 
(ICAAP) has tuned to represent a cornerstone for Pillar II of Basel accords, as well as representing such an effective risk management tool for promoting financial stability across the globe. While Pillar I of the accord concentrates on capital requirements and Pillar III on market disclosures, Pillar II acts as a form of check and balance to ensure the adequacy and credibility of the entire framework. Through the ICAAP, banks will need to demonstrate that they have implemented methods and procedures to ensure capital sufficiency at all times, with due attention to all material risks.

\subsection{Requirements of ICAAP}

Getting the ICAAP right is pivotal. This implies ensuring that the process not just concentrates on every area of the bank it should cover, yet in addition that the process and outcomes are tenable and opportune. The difficulty is represented in the way that the ICAAP requirements are principle based, as opposed to rule based, with little in the method for prescriptive calculations or perfect reporting positions for idealizing the ICAAP consistence. It is in this way critical to adjust the profundity and width of the ICAAP to accomplish the correct outcomes effectively.

According to Edgar (2005), as well as Shri (2005), Pillar I sets the rules for measuring credit, market and operational risks, and aims to align capital requirements with risks undertaken. These rules are complemented by Pillar II, which sets the requirements for internal assessment, monitoring, and controlling all material risks to which banks are exposed to.

Hence, the main objective behind the Internal Capital Adequacy Assessment Process (ICAAP) is to alert the for the progressing, the assessment and evaluation of the bank's risks, how the bank expects to mitigate those risks, and how much present and future capital is vital having considered other relieving factors intending to adequately: identifies, measures, aggregates and monitors the bank's risks, guarantees that the bank holds sufficient capital as per its risk profile, utilizes sound risk management framework, and underlines the significance of capital planning.

According to the Supervisory review process (SRP) under pillar II-BCBS, several central banks and national regulators, such as: The Central Bank of Egypt regulations (CBE, 2016b), The Federal Reserve Bank (FRB 2008, 2015), Bank of England (BoE, 2013), and The Saudi Arabian Monetary Agency (SAMA 2008, 2011); have guided their market banks in terms of the ICAAP structure they should follow according to their internal process whereby they can estimate their capital requirements in relation to their specific risk profiles, strategy, business plans, governance structures, internal risk management systems, etc. They have advised that the ICAAP should cover:

- A strategic review of the bank's capital needs, and how these capital requirements are to be funded, e.g. through internal profits, IPOs, subordinated loans, other debt issues, etc. 
- Explain how a bank would be affected by any economic recession or downswings, in the business or market relevant to its activities, for instance currency devaluation (e.g. EGP).

- Highlights how banks allow maintenance of ready access to funding, meet their obligations to creditors and other counterparties, and continue to serve as a credit intermediary prior, during and post stressful scenarios.

- Show that the capital planning processes follow a comprehensive assessment of various risks to which banks are exposed to, and the risk management processes implemented are effective and sufficient enough to manage and mitigate those risks, by turn positively affecting the financial stability of each and every bank.

Therefore, it has turned clear that the ICAAP is significantly more than a thoroughly decided estimate of capital sufficiency (Dinodia, 2014). It drives banks to assess their economic risk profile, and fulfill all stakeholders' needs confirming that that business and risks faced by banks are within their capacity and risk appetite to achieve the financial stability. It likewise intends to make banks managements mindful of and responsible for the different risks their banks are presented to, and guarantee that the business is done inside acceptable limits.

All things considered, the bank's owners and other internal and external stakeholders will be focused on its proceeded with continual operation as a business, and wish to keep away from capital misfortunes. In spite of the fact that their interests may contrast, all parties/stakeholders will likewise need to guarantee that the bank does not take risks that may jeopardize its presence. The principle rationale in presenting the ICAAP structure is to guarantee that a bank bears its risks by choice and not by chance.

\section{Data and Methodology}

This section sets out the approach and methodology for the research study analysis and case studies results. It displays a detailed process of how the significant risks facing banks, such as: The Commercial International Bank (CIB), Credit Agricole Egypt (CAE), and the Union National Bank Egypt (UNBE); are recognized, measured and managed. It is worth to be mentioned that 1 international bank and 1 regional bank (MENAP region) were identified and presented to show the ICAAP usage, effects and significance. Both banks are following the governance techniques of the ICAAP by their national regulators, e.g. The Bank of England (BoE) for HSBC-UK, and The Saudi Arabian Monetary Agency (SAMA) for Samba, KSA.

The main impact of the global latest financial crisis has been seen on the banking industry where a few banks which were performing profitably all of a sudden declared substantial losses with some of them going burst. The successful upgrading of CBE's reform plan has eased up the situation in terms of supporting the Egyptian economy and banks during tough economic conditions across 
Egypt reasoned of the latest deterioration of the national reserves and FX squeeze in the years 2014, 2015, till reaching the EGP devaluation on November the $3^{\text {rd }}, 2016$ (CBE, 2016c).

The main benchmarks utilized for this research study assessments are the different documentation, instructions and regulations issued by the Central Bank of Egypt (CBE) for Egyptian banks, and the Basel Committee on Banking Supervision (BCBS), in overall, with respect to standards which guarantee sound management of capital requirements, planning and risks in banks. The financial and economic periodical reports and bulletins issued by the Central Bank of Egypt were depended upon for the banking industry data.

\subsection{Sample and Data Sources}

Egypt has thirty nine (39) commercial banks and one (1) credit bureau registered by the Central bank of Egypt as of December 31 ${ }^{\text {st }}, 2016$. Due to the limitations in this research study that are discussed under the subtitle: Limitations of the Research Study" for item \# 1.5; the research sample is limited to the selected research study banks ( 5 banks). This is due to the difficulty faced in terms of data access and confidentiality reasons across the banking sector, Egyptian banking sector in specific, especially for the data that shall be utilized under the internal capital adequacy assessment process (ICAAP), of which the researcher has suffered a lot to obtain the required data for the research study. Therefore, the sample was only limited to those banks that are included in.

The targeted research study population has focused on: 1 international bank (HSBC, UK), 1 regional bank (Samba, KSA); both were used to highlight how the ICAAP has saved both banks/markets from economic and financial hits and instability. That is in addition to 3 Egyptian banks, 2 of the top 10 banks (Macropolis, 2015), and the third bank represents a regional Arab bank headed at the United Arab Emirates.

The discipline investigates the "how" ICAAP shall be utilized to strengthen banks financial positions through forward looking approaches and capital planning, by turn enhance the financial stability of the Egyptian market. Besides this, the researcher will also examine the model through observations in selected banks numerical financial data and through statistical analysis.

\subsection{Conceptual Framework}

This research study examines the relationship between the Banking System Stability and the Internal Capital Adequacy Assessment Process (ICAAP). The framework model is demonstrated in the following figure:

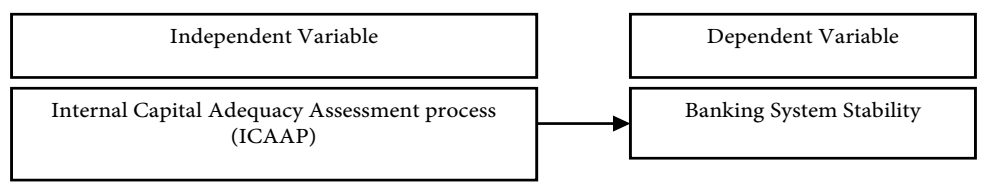

\subsection{Definitions of the Research Variables (Table 1)}


Table 1. Definitions of the research study variable.

\begin{tabular}{|c|c|c|c|}
\hline Serial & & Variable & Definitions \\
\hline 1 & $\begin{array}{l}\text { Dependent } \\
\text { Variable }\end{array}$ & $\begin{array}{l}\text { Banking and Financial } \\
\text { System Stability }\end{array}$ & $\begin{array}{l}\text { According to Garry's (2004) it is the ability to: A. encourage both a proficient allotment of } \\
\text { economic resources, both spatially and particularly inter temporally, and the adequacy of } \\
\text { other economic processes (for example wealth accumulation, economic development, and } \\
\text { ultimately social prosperity), B. assess, evaluate, allocate, and oversee financial risks; and, C. } \\
\text { keep its capacity to play out these key functions, notwithstanding when influenced by external } \\
\text { shocks or by a buildup of volatility, principally through self-remedial mechanisms. }\end{array}$ \\
\hline 2 & $\begin{array}{l}\text { Independent } \\
\text { Variable }\end{array}$ & $\begin{array}{c}\text { Internal Capital } \\
\text { Adequacy Assessment } \\
\text { Process }\end{array}$ & $\begin{array}{l}\text { According to Justin (2013), the Internal Capital Adequacy Assessment Process is de-fines as } \\
\text { the: } \\
\text { bank's internal process for assessing its overall capital adequacy in relation to its risk profile } \\
\text { and strategy for maintaining their adequate capital levels. The ICAAP should be: proportional } \\
\text { to the size and complexity of the bank, risk and capital management to match risk taking, not } \\
\text { something that should be designed only for compliance purposes, but helps to ensure that the } \\
\text { bank identifies, measures and reports all material risks (not just Pillar } 1 \text { type risks). }\end{array}$ \\
\hline 3 & $\begin{array}{l}\text { Independent } \\
\text { Variable }\end{array}$ & Pillar I Risks & $\begin{array}{l}\text { According to Edgar (2005), as well as Shri (2005), Pillar I risks are comprised of: Credit Risk, } \\
\text { Market Risk, and Operational Risk. Credit Risk is defined as the potential that a bank's } \\
\text { borrower or counterparty will fail to meet its obligations in accordance with agreed terms } \\
\text { (BCBS, 2000). Market Risk is defined as the risk of loss arising from the movements in market } \\
\text { prices such as interest rates related to instruments and equities in the trading book, or } \\
\text { exchange rates, or from fluctuations in bonds, equities or commodity prices (BCBS, 1996). } \\
\text { The Bank of International Settlements (BIS, 2011) defined the Operational Risk as the risk of } \\
\text { loss resulting from inadequate or failed internal processes, people and systems or from } \\
\text { external events. This definition includes legal risk, but excludes strategic and reputational risk. }\end{array}$ \\
\hline 4 & $\begin{array}{l}\text { Independent } \\
\text { Variable }\end{array}$ & Pillar II Risks & $\begin{array}{l}\text { According to Basel Accords (2010, 2011), Pillar II risks are those risks not captured under } \\
\text { pillar I, such as, Interest rate risk in banking book (the exposure of the bank's financial } \\
\text { condition to adverse movements in interest rates), Liquidity risk (when the bank is unable to } \\
\text { finance any increase in the assets, or to meet the liabilities when they are due, or being able to } \\
\text { carry on this with unaccepted losses), Strategic risk (external events and trends that can } \\
\text { devastate a bank's growth trajectory and shareholder value), and Reputation risk (the current } \\
\text { and prospective risk to earnings and capital arising from the adverse perception of } \\
\text { brand/image of the bank by customers, counterparties, shareholders, regulators and rating } \\
\text { agencies). The Central Bank of Egypt is following the same Basel pillar risk types and } \\
\text { definitions across the Egyptian banking market (CBE 2009a, 2012a, 2016a). }\end{array}$ \\
\hline
\end{tabular}

\section{Results and Findings}

\subsection{Results of Descriptive Statistics-EVIEWS}

Through a data extract sample for the banks under the names of HSBC-UK, and Samba Financial Group-KSA, a sample from Risk Weighted Assets (RWA), Tier 1 \& 2 capital, and Capital Adequacy Ratios (CAR) were utilized for the years starting from 2008 and ending on 2016, in addition to the first 6 months for the year 2017, see Table 2 (due to data limitation issues that were previously illustrated).

The main objective for utilizing named data is to check the impacts of the ICAAP on the final capital adequacy ratios for banks through the EVIEWS statistical analysis and conclusions.

According to the regression analysis, the results are as follows:

HSBC:

Dependent Variable: CARH, Method: Least Squares, Sample: 2008 2016, Included observations: 9 (Table 3). 
Table 2. Regression analysis and results.

\begin{tabular}{ccccccccc}
\hline \multirow{2}{*}{$\begin{array}{c}\text { Year/Bank } \\
\text { IItems }\end{array}$} & \multicolumn{3}{c}{ HSBC (in Million $\mathfrak{E})$} & \multicolumn{3}{c}{ Samba (000 SAR) } \\
\cline { 2 - 9 } & CAR & Tier 1 & Tier 2 & RWA & CAR & Tier 1 & Tier 2 & RWA \\
\cline { 2 - 9 } & CARH & Tier1H & Tier2H & RWAH & CARS & Tier 1 & Tier 2 & RWAs \\
\hline 2008 & $11.23 \%$ & 17,523 & 11,442 & 257,883 & $14.08 \%$ & $20,031,923$ & $1,516,176$ & $153,058,900$ \\
2009 & $16.72 \%$ & 22,707 & 11,272 & 203,281 & $17.12 \%$ & $22,469,344$ & $1,509,739$ & $140,085,476$ \\
2010 & $17.21 \%$ & 22,955 & 11,758 & 201,720 & $18.87 \%$ & $25,575,235$ & $1,507,250$ & $143,486,898$ \\
2011 & $15.19 \%$ & 22,739 & 11,837 & 227,679 & $19.15 \%$ & $28,231,034$ & $1,658,642$ & $156,050,317$ \\
2012 & $18.43 \%$ & 24,017 & 11,634 & 193,402 & $20.05 \%$ & $31,714,417$ & $1,696,695$ & $166,670,168$ \\
2014 & $19.20 \%$ & 24,108 & 11,582 & 185,879 & $19.40 \%$ & $34,954,464$ & $1,569,404$ & $188,295,390$ \\
2015 & $13.77 \%$ & 25,138 & 8,418 & 243,652 & $19.86 \%$ & $38,798,653$ & $1,442,075$ & $202,580,614$ \\
2016 & $15.52 \%$ & 27,017 & 8,586 & 229,382 & $20.06 \%$ & $40,237,264$ & $1,209,835$ & $206,643,117$ \\
Jun-2017 & $15.71 \%$ & 30,218 & 8,304 & 245,237 & $22.46 \%$ & $42,810,511$ & $1,223,471$ & $196,082,355$ \\
\hline
\end{tabular}

Data Sources: HSBC (2008-2017), and SAMBA (2008-2017) annual reports for the years starting of 2008 until 2016, and the first 6 months for 2017.

Table 3. Regression results, HSBC.

\begin{tabular}{ccccc}
\hline Variable & Coefficient & Std. Error & t-Statistic & Prob. \\
\hline C & 18.94291 & 3.69461 & 5.127174 & 0.0037 \\
RWAH & $-7.35 \mathrm{E}-05$ & $5.78 \mathrm{E}-06$ & -12.7153 & 0.0001 \\
TIER1H & 0.000379 & $5.20 \mathrm{E}-05$ & 7.295404 & 0.0008 \\
TIER2H & 0.000386 & 0.000136 & 2.844152 & 0.0361 \\
R-squared & 0.993655 & Mean dependent var & & 15.88667 \\
Adjusted R-squared & 0.989849 & S.D. dependent var & Akaike info criterion & 0.416304 \\
S.E. of regression & 0.243451 & Schwarz criterion & & 0.4009304 \\
Sum squared resid & 0.296343 & F-statistic & 261.0255 \\
Log likelihood & 2.590133 & Prob(F-statistic) & 0.000007 \\
Durbin-Watson stat & 1.766312 & & \\
\hline
\end{tabular}

Samba:

Dependent Variable: CARH, Method: Least Squares, Sample: 2008 2016, Included observations: 9 (Table 4).

Regression Results Interpretation:

- The Variable RWA: The coefficient is showing in negative signs, which means inverse relationship on the capital adequacy ratio $(\mathrm{CAR}=\mathrm{T} 1+$ T2/RWAs), and the 2 negatives are showing a positive relationship on the capital (HSBC -7.35E-05 and SAMBA -1.14E-07).

- The Probability: Figures are showing values that are lower than 5\% across the analysis, which means that the three selected variables (RWA, Tier 1 and 2) have effects on CAR with confidence level of the selected variables of more than $95 \%$ which is very good to take into consideration. 
Table 4. Regression results SAMBA.

\begin{tabular}{ccccc}
\hline Variable & Coefficient & Std. Error & t-Statistic & Prob. \\
\hline C & 16.85307 & 1.081239 & 15.58682 & 0 \\
RWAH & $-1.14 \mathrm{E}-07$ & $6.38 \mathrm{E}-09$ & -17.93654 & 0 \\
TIER1H & $6.10 \mathrm{E}-07$ & $2.03 \mathrm{E}-08$ & 30.10083 & 0 \\
TIER2H & $1.75 \mathrm{E}-06$ & $4.49 \mathrm{E}-07$ & 3.893299 & 0.0115 \\
R-squared & 0.996652 & Mean dependent var & & 19.00556 \\
Adjusted R-squared & 0.994643 & S.D. dependent var & & 2.315092 \\
S.E. of regression & 0.169453 & Akaike info criterion & & -0.41138 \\
Sum squared resid & 0.143571 & Schwarz criterion & & -0.32373 \\
Log likelihood & 5.851221 & F-statistic & & 496.0795 \\
Durbin-Watson stat & 2.138418 & Prob (F-statistic) & & 0.000001 \\
\hline
\end{tabular}

- R-squared: The coefficient is showing a percentage of $99 \%$ and plus, which means that the three selected variables (RWA, Tier 1 and 2) changes affect with $99 \%$ the changes in CAR. The balance of $1 \%$ and minus represents a residual that affects CAR other than the three selected variables.

- Durbin-Watson stat (DW): For proper regression, the DW is highly recommended be close to the Figure 2. According to the selected sample, both banks and variables were following the same proper DW benchmarks; HSBC-1.766312, and Samba-2.138418.

- Therefore, and as a conclusion based on the regression analysis and results: The ICAAP shows a clear significant relationship on Banks Systems Stability through the comprehensive assessment of banks overall capital adequacies in relation to their risk profiles; for maintaining adequate and stable forward looking capital levels.

\subsection{Results of HSBC-UK}

HSBC represents one of the largest banking and financial services organizations in the world. In line with HSBC's ambition to be recognized as the world's leading international bank, the bank has continued to reinforce the status and significance of compliance and adherence to new global standards and regulations by building strong risk management tools, e.g. ICAAP programs, internal controls, developing risk culture platforms and capabilities through communication, training and assurance programs to make sure employees understand and can meet their responsibilities effectively.

Accordingly, HSBC has conducted its Internal Capital Adequacy Assessment Process (ICAAP) to determine a forward looking assessment of its capital requirements given its business strategy, risk profile, risk appetite and capital plan according to the bank's annual report and financials for the year ending 2013 (HSBC, 2013. See Table 5). This process has incorporated the risk management processes and governance of the bank. A range of stress tests were applied to the 
Table 5. Capital adequacy ratio, HSBC, 2012, 2013.

\begin{tabular}{ccc}
\hline \multicolumn{3}{c}{ Capital Adequacy Ratio } \\
\hline & December, 2013 actual figures \\
\hline Items & Actual 31/12/2013 & (Million $\mathfrak{E})$ \\
\hline Total Capital Base & $\mathbf{3 3 , 5 4 3}$ & $\mathbf{3 3 , 4 6 4}$ \\
Tier 1 capital & 22,438 & 22,088 \\
Tier 2 capital & 11,105 & 11,376 \\
Total RWA & $\mathbf{1 8 5 , 8 7 9}$ & $\mathbf{1 9 3 , 4 0 2}$ \\
Credit Risk & 145,909 & 149,970 \\
Market Risk & 17,931 & 21,566 \\
Operational Risk & 22,039 & 21,866 \\
Actual CAR \% & $\mathbf{1 8 \%}$ & $\mathbf{1 7 \%}$ \\
\hline
\end{tabular}

base capital plan. These, coupled with the bank's risk management practices were used to assess the capital adequacy requirements.

Based on Tier 1 and Tier 2 capital figures, as well as risk weighted assets (RWA), the CAR ratios for HSBC as of December 31st, 2013 (HSBC, 2013) are represented at Table 5 .

Highlighting the effective usage of the ICAAP by HSBC, as well as reflecting its significant impact on the bank's financial stability, the Brexit scenario and its impacts on the CAR ratio and capital planning was taken into consideration even prior to the poll results with 3 years (HSBC, 2013), the well managed preparation to face such a potential scenario in case occurred, coupled with its forecasted adverse impacts, if any, on UK in general, and English banks in specific was well studied within the ICAAP program not leaving the bank to manage risks by chance not by choice. The CAR ratios (see Table 6) scopes the capital adequacy thresholds achieved between December 2013, 2016 and June 2017 showing named ICAAP forward looking effect.

This illustration has shed the light on:

- How the ICAAP has saved the bank from a possible hit that might have affected the bank's stability, and its capability to implement planned strategies and objectives in case of the UK's being out of the EU discretionary, beforehand, even if it did not happen, or the effect was not adverse; still being considered proactively with possible accounted effects.

- Showing clearly the direct effect of the increase in risk weighted assets (RWAs) on the capital adequacy ratios model (CAR), which has increased from $£ 186$ million in December 2013 to reach $£ 245$ million in December 2016 (32\% increase), before it decreased to score $£ 240$ million on June, 2017 (total capital base has increased with $15 \%$ on December 2016 as being compared to the same period of 2013, and $2 \%$ on June 2017 as compared to FY 2016 figures). Simultaneously, how management has succeeded to use capital injections, mainly tier 1 capital ( $£ 22$ million on FY 2013, increased to reach

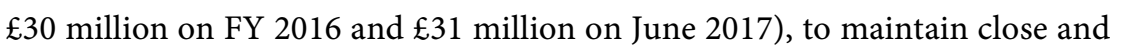
safe CAR ratios and overcome any decreases or possible hits. 
Table 6. Capital adequacy ratio, HSBC, 2013, 2016.

\begin{tabular}{cccc}
\hline \multicolumn{4}{c}{ Capital Adequacy Ratio } \\
\hline & June 2017 - December 2016 - December 2013 & (million $\mathfrak{E})$ \\
\hline Items & Interim 30/06/2017 & Actual 31/12/2016 & Actual 31/12/2013 \\
\hline Total Capital Base & 39,274 & $\mathbf{3 8 , 5 2 2}$ & $\mathbf{3 3 , 5 4 3}$ \\
Tier 1 capital & 31,150 & 30,218 & 22,438 \\
Tier 2 capital & 8,124 & 8304 & 11,105 \\
Total RWA & 239,703 & 245,237 & 185,879 \\
Credit Risk & 194,547 & 197,529 & 145,909 \\
Market Risk & 22,423 & 24,975 & 17,931 \\
Operational Risk & 22,733 & 22,733 & 22,039 \\
Actual CAR \% & $16 \%$ & $16 \%$ & $18 \%$ \\
\hline
\end{tabular}

Data Source: HSBC 2013, 2016, H1 2017.

- That besides on answering on the research study question as: There is a significant relationship between the Banking System Stability and the Internal Capital Adequacy Assessment Process (ICAAP).

\subsection{Results of SAMBA, The Kingdom of Saudi Arabia}

Samba Financial Group represents one of the main Saudi listed banks by the Saudi Arabia Monetary Authority (SAMA) which represents the Saudi national regulator that is a permanent member of the G20, in addition of having presence within the Middle East region and Pakistan (e.g. Samba Dubai, and Samba Pakistan).

Accordingly, Samba has conducted an Internal Capital Adequacy Assessment Process (ICAAP) to determine a forward looking assessment of its capital requirements given its business strategy, risk profile, risk appetite and capital plan according to the bank's annual report and financials for the year ending 2013 (SAMBA, 2013. See Table 7). This process has incorporated the risk management processes and governance of the bank. A range of stress tests were applied to the base capital plan. These, coupled with the bank's risk management practices were used to assess the capital adequacy requirements.

Based on Tier 1 and Tier 2 capital figures, as well as risk weighted assets (RWA), the CAR ratios for Samba as of December 31st, 2013 (SAMBA, 2013) are represented at Table 7.

According to the illustrated CAR ratios, it has shed the light on:

- Showing clearly the direct effect of the increase in risk weighted assets (RWAs) on the capital adequacy ratios model (CAR), which has increased from Saudi Riyals-SAR 167 billion in December 2012 to reach SAR 188 billion in December 2016 (13\% increase), simultaneously, the total capital base has increased with $9 \%$ on December, 2013 as being compared to the same 
Table 7. Capital ADEQUACY RATIO, SAMBA, 2012, 2013.

\begin{tabular}{ccc}
\hline \multicolumn{3}{c}{ Capital Adequacy Ratio } \\
\hline & December, 2013 actual figures & \\
\hline Items & Actual 31/12/2013 & Actual 31/12/2012 \\
\hline Total Capital Base & $36,523,868$ & $33,411,112$ \\
Tier 1 capital & $34,954,464$ & $31,714,417$ \\
Tier 2 capital & $1,569,404$ & $1,696,695$ \\
Total RWA & $188,295,390$ & $166,670,168$ \\
Credit Risk & $161,664,756$ & $142,000,392$ \\
Market Risk & $14,967,138$ & $12,936,644$ \\
Operational Risk & $11,663,496$ & $11,733,132$ \\
Actual CAR \% & $19 \%$ & $\mathbf{2 0} \%$ \\
\hline
\end{tabular}

period of 2012 figures, witnessing the increase mainly at pillar 1 capital (from SAR 32 billion on FY 2012 to SAR 35 billion on FY 2013, representing a 10\% increase), ending with an approximately flat change on the CAR ratios of FY $2013 / 2012$ of $19.40 \%$ and $20.05 \%$ respectively.

- Based on the ICAAP's consideration for the three year plan and strategy, as well as stress testing employment to test against set targets according to prescribed scenario analysis; the ICAAP has been designed to ensure that the bank holds sufficient capital cushion to meet regulatory and internal capital requirements during periods of cyclical economic downturns or during times of financial distress, so that any potential large inorganic growth or deterioration in the economic environment will be addressed at the appropriate time. Accordingly, the ICAAP has saved Samba from the aggressive hit that has adversely affected, in overall, the KSA and the Gulf region (GCC) due to the massive fall in oil prices that has fallen sharply from USD 97.18 per barrel in 2014, to reach USD 40.96 on December 2016 (SAMA, 2016).

The CAR ratios (see Table 8) scope the capital adequacy thresholds between December 2016, 2015, 2014, 2013 and June 2017 showing the numerical impacts (SAMBA, June, 2017, December 2016, 2015, 2014, and 2013).

This illustration has clarified that:

- The ICAAP has saved the bank from a very possible hit that might have affected the bank's stability and its capability to implement planned strategies and objectives due to the massive dipping curves in oil prices for the years 2014, 2015 and 2016 that has affected all members of the Organization of the Petroleum Exporting Countries (OPEC), KSA in specific being one of the world's largest oil exporters, of which oil represents a major revenue stream to the gulf region countries (GCC).

- Operationalize the evidenced answer on the research study questions: How can the ICAAP be used to limit or promote risk taking activities in order to 
Table 8. Capital adequacy ratio, SAMBA, 2013, 2014, 2015, 2016, 2017.

\begin{tabular}{|c|c|c|c|c|c|}
\hline \multicolumn{6}{|c|}{ Capital Adequacy Ratio } \\
\hline \multicolumn{6}{|c|}{ Interim June, 2017 - Actual December 2013 to December 2016} \\
\hline & & & & & (000 SAR) \\
\hline Items & $\begin{array}{c}\text { Interim } \\
30 / 06 / 2017\end{array}$ & $\begin{array}{c}\text { Actual } \\
31 / 12 / 2016\end{array}$ & $\begin{array}{c}\text { Actual } \\
31 / 12 / 2015\end{array}$ & $\begin{array}{c}\text { Actual } \\
31 / 12 / 2014\end{array}$ & $\begin{array}{c}\text { Actual } \\
31 / 12 / 2013\end{array}$ \\
\hline $\begin{array}{c}\text { Total Capital } \\
\text { Base }\end{array}$ & $45,002,788$ & $44,033,982$ & $41,447,099$ & $40,240,728$ & $36,523,868$ \\
\hline Tier 1 cap. & $43,863,987$ & $42,810,511$ & $40,237,264$ & $38,798,653$ & $34,954,464$ \\
\hline Tier 2 cap. & $1,138,801$ & $1,223,471$ & $1,209,835$ & $1,442,075$ & $1,569,404$ \\
\hline Total RWA & $228,981,479$ & $196,082,355$ & $206,643,117$ & $202,580,614$ & $188,295,390$ \\
\hline Credit Risk & $202,040,921$ & $171,634,477$ & $181,689,185$ & $173,822,138$ & $161,664,756$ \\
\hline Market Risk & $13,636,938$ & $11,325,363$ & $11,862,675$ & $16,570,138$ & $14,967,138$ \\
\hline $\begin{array}{l}\text { Operational } \\
\text { Risk }\end{array}$ & $13,303,620$ & $13,122,515$ & $13,091,257$ & $12,188,338$ & $11,663,496$ \\
\hline Actual CAR \% & $20 \%$ & $22 \%$ & $20 \%$ & $20 \%$ & $19 \%$ \\
\hline
\end{tabular}

ensure the continuing financial strength of the bank, and answering on the research study question showing that there is a significant relationship between the Banking System Stability and the Internal Capital Adequacy Assessment Process (ICAAP).

\subsection{Results of Commercial International Bank (CIB) Egypt}

The CIB represents the biggest private bank in Egypt. Based on Tier 1 and Tier 2 capital figures (see Table 9), Table 9 shows risk weighted assets (RWA) and the CAR ratios for CIB as of December $31^{\text {st }}, 2016$ (CIB, 2016).

Based on the presented CIB CAR analysis for the period ending on December

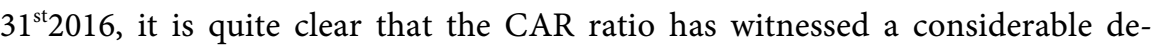
crease from 16.06\% on December 2015 to reach 10.74\% on December 2016 with a dipping down percentage of 33\%; which is very close to the minimum capital requirements set by CBE regulations (CBE, 2016d) of 10.6\% in 2016, and falling short than January 2017 minimum capital requirements of $11.25 \%$. The decrease was mainly attributed to:

- Increase in total Credit Risk RWAs from EGP 79 billion on December 2015 to reach EGP 128 billion on December 2016 with an increase of 62\%, which is mainly attributed to the increase in the loans and advances portfolio from EGP 62 billion by the end of 2015 to EGP 98 billion on FY 2016 (58\% increase). The main reason of this hike was mainly due to the increase in the value of foreign currency assets post the local currency devaluation in Egypt effective November 3rd, 2016, ending with the increase in foreign currency assets as being compared to EGP values (which has increased from 1 USD = EGP 8.90 on November 2nd 2016, to reach EGP 12.90 on the first free float day effective November 3rd, 2016, and increasing to reach approximately EGP 20.00 on December 31st, 2016 as an average FX change figure across the market. CBE, 2016d). 
Table 9. Capital adequacy ratio, CIB, 2015, 2016.

\begin{tabular}{ccc}
\hline \multicolumn{3}{c}{ Capital Adequacy Ratio } \\
\hline & December, 2016 (scenario 1: actual scenario) \\
\hline Items & Actual 31/12/2016 & $(000 \mathrm{EGP})$ \\
\hline Total Capital Base & $16,120,502$ & Actual 31/12/2015 \\
Tier 1 capital & $14,509,944$ & $15,355,371$ \\
Tier 2 capital & $1,610,558$ & $14,350,155$ \\
Total RWA & $150,097,333$ & $1,005,216$ \\
Credit Risk & $128,698,992$ & $95,619,994$ \\
Market Risk & $6,701,579$ & $79,363,222$ \\
Operational Risk & $14,696,762$ & $4,030,779$ \\
Actual CAR \% & $10.74 \%$ & $12,225,993$ \\
\hline
\end{tabular}

- Increase in Market Risk and Operational Risk RWAs for the same comparable period from EGP 4 billion and EGP 12 billion (2015); to EGP 6 billion and 15 billion on December 2016 respectively. Reasons for this increase was attributed to the whole market's increase in terms of investing in fixed income financial instruments (e.g. Governmental bonds and Treasury Bills) for the mentioned period, besides the increase in the net profit for 2016 (EGP 5.9 billion) than in 2015 (EGP 4.6 billion) which is shedding as an indicator for gross profit increase as the bank is following the Basic Indicator approach (BIA) for operational risk calculations (based on the average gross profit for the last 3 profitable years).

- Impacts: Recognizable decrease for CAR ratio with 33\% downturn, due to the increase in risk weighted assets (RWA) as per CBE rules (CBE 2009d, 2016e) and Basel's recommendations (BCBS, 2011b), without any considerable increase at the bank's capital that can absorb these hikes at RWAs on December 31st, 2016. This impact is showing clearly the direct effect of the increase in risk weighted assets (RWA) on the capital adequacy ratios model (CAR), which by turn affects the financial stability of the bank and its capability to implement approved strategies and objectives accordingly.

Based on all the mentioned facts, strategy and business plan/directives of the bank, as well as the bank's acknowledgment in terms of abiding to CBE's SRP rules, and Basel III standards (CIB 2016, 2017), the ICAAP program was used to assess: the overall risks the bank is facing/will face, internal models to assess, quantify and stress test risk drivers and the amount of capital required to support the same. The bank has followed the benchmark set by several national regulators, for instance the Central Bank of Egypt regulations (CBE, 2016e), in terms of the ICAAP's governance, principles, and report structure.

The ICAAP has concluded that: Based on CIB's existing CAR ratios, it is quite clear that the bank shall face a serious shortcoming; due to falling below the 
minimum capital requirements set by CBE that shall start on January 2017 (CBE, 2016 e) of $11.25 \%$ against CIB's CAR ratio of $10.74 \%$ on the year ending December 2016. This fact shall hinder the bank's ability to achieve its objectives in terms of increasing its market share, expanding within the market across all business lines, and utilizing new technological platforms as per approved strategy. It is to be noted that based on the research study limitations mentioned; the detailed data for pillar 2 risks, and budget business plan were not available.

The ICAAP has managed for the analysis of the potential capital deviations and amendments/enhancement needs according to the capital planning that should be matching with: Planned expansion and growth rates, in addition to satisfying the tolerance rates as per $\mathrm{CBE}$ regulations for the minimum capital requirements, avoid any possible breach for the regulatory limits that is showing to potentially occur on January 2017, support the bank's expansion, and maintain a safe buffer over the prescribed regulatory capital adequacy ratio as per the bank's risk appetite statement derived through the ICAAP. Several recommendations for capital increase were submitted based on the assessment, for instance through: increase in capital through fresh funds of equity shares by new/existing shareholders, or through interim profits recognization and retained earnings; to bolster the bank's capital levels and capital adequacy figures. All recommendations are subject to: CBE rules and approvals, as well as the bank's general assembly's approval.

Based on the ICAAP assessment and recommendations, Table 10 presents the amended capital status (through interim profits recognization and retained earnings) and conclusions (CIB, 2016, 2017):

Conclusions and Recommendations:

- The ICAAP has preserved the bank's new strategy, growth plans, regulatory requirements through the forecasted decrease in CAR ratios on December 2016 as being compared to the same period on 2015, coupled with recommendations submission for enhancing capital levels that has reached on a first phase $13.97 \%$ with an increase of $30 \%$ (through retained earnings).

- All have clearly showed how the ICAAP has a significant and positive impact on strengthening the financial stability of CIB during such a critical phase for the Egyptian economy, whether due to a burdensome agenda of a high budget deficit, foreign currency shortage, rising inflation rates, an ailing tourism sector, or the massive decreasing trends for remittances, FDIs and Suez Canal revenues.

- Operationalize the evidenced answer on the research study question in terms of shedding the light towards the significant relationship between the Banking System Stability and the Internal Capital Adequacy Assessment Process (ICAAP).

\subsection{Results of Credit Agricole (CAE) Egypt}

Credit Agricole Egypt is a subsidiary of the Credit Agricole Group, a market pioneer at the universal banking and represents one of the largest banking groups 
Table 10. Capital adequacy ratio, CIB, 2016.

\begin{tabular}{ccc}
\hline \multicolumn{3}{c}{ Capital Adequacy Ratio } \\
\hline December, 2016 (scenario 2: amended scenario) \\
\hline Items & (000EGP) \\
\hline Total Capital Base & Amended 31/12/2016 & Base 31/12/2016 \\
Tier 1 capital & $20,965,797$ & $16,120,502$ \\
Tier 2 capital & $19,355,239$ & $14,509,944$ \\
Total RWA & $1,610,558$ & $1,610,502$ \\
Credit Risk & $150,097,333$ & $150,097,333$ \\
Market Risk & $128,698,992$ & $128,698,992$ \\
Operational Risk & $6,701,579$ & $6,701,579$ \\
Actual CAR \% & $14,696,762$ & $14,696,762$ \\
& $13.97 \%$ & $10.74 \%$ \\
\hline
\end{tabular}

across the globe. Based on Tier 1 and Tier 2 capital figures presented at Table 11, it clarifies the risk weighted assets (RWA), and the CAR ratios for CAE as of December 31st, 2016 (CAE, 2016):

Based on the presented CAR for the period ending on December $31^{\text {st }}, 2016$, it is quite clear that the CAR ratio has witnessed a decrease from $14.39 \%$ on December $31^{\text {st }}, 2015$ to reach $11.57 \%$ on December 31st, 2016 with a considerable decrease of $20 \%$; which is very close to the minimum capital requirement levels set by CBE regulations (CBE, 2016d) of 10.6\% in 2016, and $11.25 \%$ starting from January 2017. The decrease was mainly attributed to:

- Increase in total Credit Risk RWAs from EGP 14 billion on December 2015 to EGP 20 billion on December 2016 with an increase of $40 \%$, which is mainly attributed to the increase in the loans and advances portfolio from EGP 14 billion by the end of 2015 to EGP 19 billion on 2016 (36\% increase). The main reason due to this increase was mainly reasoned of the increase in the value of foreign currency assets post the local currency devaluation effective November 3rd, 2016, ending with the increase in foreign currency assets as being compared to EGP values (which has increased from 1 USD = EGP 8.90 on November 2nd 2016, to reach EGP 12.90 on the first free float day effective November 3r, 2016 and approximately reaching EGP 20.00 on December ending 2016 as an average FX change figures across the Egyptian market, CBE, 2016b).

- Increase in Market Risk and Operational Risk RWAs for the same comparable period from EGP 92 million and EGP 2.9 billion (2015); to EGP 154 million and 3.4 billion on December, 2016 respectively. Reasons for this increase was attributed to the whole market's increase in terms of investing in fixed income financial instruments (e.g. Governmental bonds and Treasury Bills) for the mentioned period, besides the increase in the net profit for 2016 (EGP 1.36 billion) than 2015 (EGP 1.03 billion) which is shedding as indicator for 
Table 11. Capital adequacy ratio, CAE, 2015, 2016.

\begin{tabular}{ccc}
\hline \multicolumn{3}{c}{ Capital Adequacy Ratio } \\
\hline December, 2016 (scenario 1: actual scenario) \\
\hline Items & (000EGP) \\
\hline Total Capital Base & Actual 31/12/2016 & Actual 31/12/2015 \\
Tier 1 capital & $\mathbf{2 , 8 2 7 , 5 9 3}$ & $\mathbf{2 , 5 6 9 , 7 7 0}$ \\
Tier 2 capital & $2,530,903$ & $2,352,631$ \\
Total RWA & 296,690 & 217,139 \\
Credit Risk & $\mathbf{2 4 , 4 4 3 , 2 5 5}$ & $\mathbf{1 7 , 8 5 6 , 4 9 4}$ \\
Market Risk & $20,840,408$ & $14,855,976$ \\
Operational Risk & 154,366 & 92,958 \\
Actual CAR \% & $3,448,481$ & $2,907,561$ \\
& $11.57 \%$ & $14.39 \%$ \\
\hline
\end{tabular}

gross profit increase as the bank is following the Basic Indicator approach (BIA) for operational risk calculations (based on the average gross profit for the last 3 profitable years).

- Impacts: Recognizable decrease for CAR ratio with $20 \%$ downturn, due to the increase in risk weighted assets (RWA) as per CBE rules (CBE 2009a, 2016a) and Basel's recommendations (BCBS, 2011b), without any considerable increase at the bank's capital that can absorb this hike at RWAs as of December 31st, 2016.

Based on all mentioned facts, figures, strategy and business plan/directives of the bank, as well as the bank's acknowledgment in terms of abiding to CBE's SRP rules, and Basel III standards (CBE, 2016b), accordingly, the ICAAP was utilized to screen: the overall risks the bank is facing/will face, internal models to assess, quantify and stress test risk drivers and factors and the amount of capital required to support the same. The bank has followed the benchmark set by several national regulators, for instance the Central Bank of Egypt regulations (CBE, 2016b).

The ICAAP has concluded that: Based on the presented CAR ratios, the bank shall face a serious situation due to the fact that its capital shall not be sufficient enough to achieve approved strategies and plans due to being fixed standard for January 2017 minimum capital requirements of $11.25 \%$ as per CBE rules (CAE's ratio has scored only $11.57 \%$ on December 31st, 2016). This fact shall represent such a challenge and obstacle towards the bank's ability to achieve its increase in its market share, and utilizing new technological platforms and acquiring new customers through the inclusion utilizing digital channels. It is to be noted that based on the research study limitations mentioned; the detailed data for pillar 2 risks, and budget business plan were not available.

The ICAAP has managed for the analysis of potential capital deviations according to the capital planning that should be matching with: Planned expansion 
and growth rates, in addition to satisfying the tolerance rates as per CBE regulations for minimum capital requirements, avoid any possible breach to the regulatory limits that according to January 2017 regulatory rules, support the bank's expansion and maintaining a safe buffer over the prescribed regulatory capital adequacy ratio as per bank's risk appetite statement derived through the ICAAP.

Several recommendations for capital increase were submitted based on the assessment, for instance through: increase in capital through interim profit recognization based on the approvals of the general assembly and CBE (FY 2016, and the period ending Q2 2017) or subordinated loans from the bank owners and complying with the Central Bank's of Egypt regulations (CBE, 2017a). All recommendations are subject to: CBE rules and approvals, as well as the bank's general assembly's approval.

Based on the ICAAP assessment and recommendations, Table 12 presents the amended capital status (post receiving the subordinated loans from the bank owners of USD 30 million) and conclusions.

Conclusions and Recommendations:

- The ICAAP has preserved the bank's new strategic directives, growth plans, regulatory requirements through the forecasted decrease in CAR ratios on December 2016 as being compared to the same period on 2015, coupled with recommendation for enhancing capital levels that has reached $18.85 \%$ on June 2017 representing one of the highest CAR ratios across the Egyptian banking market, and higher than the benchmark CAR ratio across the banking market on June 2017 which scored 14.1\% on December 2016 (CBE, $2017 \mathrm{~b}$ ) through the injection of approved interim profit recognization and the subordinated loan.

- All have clearly shown how the ICAAP had a significant and positive impact on strengthening the financial stability of CAE during such a critical phase for the Egyptian economy, whether due to the burdensome agenda of a high budget deficit, foreign currency shortage, rising inflation rates, an ailing tourism sector, or the massive decreasing trends for remittances, FDIs and Suez Canal revenues.

- Operationalize the evidenced answer on the research study question: How can the ICAAP be used to limit or promote risk taking activities in order to ensure the continuing financial strength of the bank, and showing the direct and significant relationship between the Banking System Stability and the Internal Capital Adequacy Assessment Process (ICAAP).

\subsection{Results of Union National Bank (UNBE) Egypt}

Union National Bank Egypt is a subsidiary of the Union National Banking Group in UAE, represents one of the largest banking groups across the at Middle East region. Based on Tier 1 and Tier 2 capital figures, Table 13 sheds the light on the risk weighted assets (RWA) and the CAR ratios as of December 2016 (UNBE, 2016): 
Table 12. Capital adequacy ratio, CAE, 2016, 2017.

\begin{tabular}{ccc}
\hline \multicolumn{3}{c}{ Capital Adequacy Ratio } \\
\hline \multicolumn{2}{c}{ June, 2017 (scenario 2: amended scenario) } \\
\hline Items & (000EGP) \\
\hline Total Capital Base & $\mathbf{3 0 / 0 6 / 2 0 1 7}$ & Base 31/12/2016 \\
Tier 1 capital & $\mathbf{4 , 8 8 4 , 3 7 8}$ & $\mathbf{2 , 8 2 7 , 5 9 3}$ \\
Tier 2 capital & $4,025,959$ & $2,530,903$ \\
Total RWA & 858,419 & 296,690 \\
Credit Risk & $\mathbf{2 5 , 9 1 1 , 9 5 5}$ & $\mathbf{2 4 , 4 4 3 , 2 5 5}$ \\
Market Risk & $22,308,614$ & $20,840,408$ \\
Operational Risk & 154,860 & 154,366 \\
Actual CAR \% & $3,448,471$ & $3,448,481$ \\
\hline
\end{tabular}

Data Sources: CAE 2017, 2016. Top 50 concentration value (EGP 512 million) is added on the Credit Risk RWAs.

Table 13. Capital adequacy ratio, UNBE, 2016-2017.

\begin{tabular}{ccc}
\hline \multicolumn{3}{c}{ Capital Adequacy Ratio } \\
\hline December, 2016 (scenario 1: actual scenario) \\
\hline Items & $(000 \mathrm{EGP})$ \\
\hline Total Capital Base & Actual 31/12/2016 & Actual 31/12/2015 \\
Tier 1 capital & $1,656,805$ & $1,542,888$ \\
Tier 2 capital & $1,563,283$ & $1,466,078$ \\
Total RWA & 93,522 & 76,810 \\
Actual CAR \% & $14,735,426$ & $\mathbf{6 , 9 9 0 , 0 1 0}$ \\
& $11.25 \%$ & $\mathbf{2 2 . 0 7 \%}$ \\
\hline
\end{tabular}

Based on the illustrated CAR ratios for the period ending on December $31^{\text {st }}$, 2016 and onwards, it is quite clear that the CAR ratio had witnessed a major decrease from $22.07 \%$ on December $31^{\text {st }}, 2015$ to reach $11.25 \%$ on December $31^{\text {st }}$, 2016 with a dipping down percentage of $49 \%$ which was alerting, very close to the minimum requirement set by CBE regulations (CBE, 2016e) of $10.62 \%$ in December 2016, and marginal standard on January 2017 minimum capital requirements (11.25\%). This decrease was mainly attributed to:

- Increase in total Credit Risk RWA from EGP 6.2 billion on December 2015 to EGP 8.5 billion on December, 2016 with an increase of 37\%, which was mainly attributed to the increase in loans and advances portfolio from EGP 5.7 billion by the end of 2015 to EGP 8.6 billion on 2016, with an increase of $51 \%$. The main reason was due to this hike in the value of foreign currency assets post the local currency devaluation effective November 3rd, 2016, 
ending with the increase in foreign currency assets as being compared to EGP values (which has increased from 1 USD = EGP 8.90 on November 3rd, 2016, to reach EGP 12.90 on the first free float day on November 3rd, 2016 and approximately EGP 20.00 on December 31st, 2016 as an average FX change figures across the market, CBE 2016c).

- Increase in total market risk charges from EGP 24 million on December 2015 to EGP 487 million on December 2016; which represented a multiplier of 19 times greater than base year's values. The main reason for such a basic increase was represented in terms of investments at fixed income portfolios and instruments in USD and EUR currencies (e.g. Governmental bonds and Treasury Bills) for the mentioned period, which besides the increase in the value of foreign currency assets post the local currency devaluation effective November 3rd, 2016, has ended up with such a massive increase in market risk values accordingly (CBE, 2016d).

- Impacts: CAR ratio has fallen down, very close to the minimum requirement set by CBE regulations (CBE, 2016c) of 10.6\% in December 2016, and marginal standard on January 2017 minimum capital requirements (11.25\%) according to the minimum capital requirements set by the $\mathrm{CBE}$ and Basel III (CBE 2016c, Basel 2011).

Based on all mentioned facts, figures, strategy and business plan/directives of the bank, as well as the bank's acknowledgment in terms of abiding to CBE's SRP rules, and Basel III standards (CBE, 2016e), accordingly, the ICAAP was utilized to screen: the overall risks the bank is facing/will face, internal models to assess, quantify and stress test risk drivers and factors and the amount of capital required to support the same. The bank has followed the benchmark set by several national regulators, for instance the Central Bank of Egypt regulations (CBE, 2016a).

The ICAAP has concluded that: Based on the presented CAR ratios, the bank shall face a serious situation due to the fact that its capital shall not be sufficient enough to achieve approved strategies and plans due to being fixed standard for January 2017 minimum capital requirements of $11.25 \%$ as per CBE rules. This fact shall represent such a challenge and obstacle towards the bank's ability to achieve its market share expansion within the Egyptian market. It is to be noted that based on the research study limitations mentioned; the detailed data for pillar 2 risks, and budget business plan were not available.

Several options for capital increase were set, for instance: Increase in capital funds through fresh equity shares, injections through interim profits recognization (subject to the approvals of the general assembly, and CBE), or subordinated facilities from the main shareholders according to CBE rules (CBE 2009b, 2017a), amending the bank's risk profile and strategy through reducing a particular activity or group of activates to reduce risks, and enhancing the bank internal utilized models.

Based on the ICAAP's identified risk factors, outlined methodology adopted 
for computing the capital requirements, Table 14 shows the amended CAR ratios of the bank (see Table 14) based on the selection of the profits distribution plan, and the subordinated loan consideration (USD 50 million) as being represented as the ICAAP's corrective action plan and effects (UNBE, 2016-2017).

Amended capital adequacy ratios (CAR) had reached 13\% according to June 2017 figures, which has increased with 15\% than December closing figures, and over the minimum CAR ratio required by the CBE with $15 \%$ on a more safe zone area.

Therefore, the ICAAP has preserved the bank against: falling below the regulatory minimum capital requirements, the inability to achieve the planned strategic directives, and growth plans. It has also supported the bank in terms of enhancing its capital level that has reached $13 \%$ on June, 2017 compared to $11 \%$ which was close to the CBE minimum regulatory limits on December 2016 (10.6\% for December 2016) based on the direct effect of the approved injection approved of profits distribution and the subordinated loan. All have clearly shown how the ICAAP have a significant impact on saving the bank against falling below regulatory requirements, adversely affecting the bank's strategy implementation and growth plans, bank's repetition, strengthening the financial stability of the bank during such a critical phase for the Egyptian economy, whether with due to the foreign currency shortage, rising inflation rates, or the massive decreasing trends for remittances, FDIs and Suez Canal revenues.

Also, the ICAAP has focused the light towards the evidenced answer on the research study questions: How can the ICAAP be used to limit or promote risk taking activities in order to ensure the continuing financial strength of the bank, and the fulfillment of the regulatory requirements, as well as shedding the light towards the significant answering relationship between the Banking System Stability and the Internal Capital Adequacy Assessment Process (ICAAP).

\section{Conclusion of the Findings}

This research study has examined the significant relationship between the Banking System Stability and the Internal Capital Adequacy Assessment Process

Table 14. Capital adequacy ratio, UNBE, 2016-2017.

\begin{tabular}{ccc}
\hline \multicolumn{3}{c}{ Capital Adequacy Ratio } \\
\hline June, 2017 (scenario 2: amended scenario) \\
\hline Items & (000EGP) \\
\hline Total Capital Base & Actual 31/12/2016 & June 2017 \\
Tier 1 capital & $1,656,805$ & $1,997,360$ \\
Tier 2 capital & $1,563,283$ & $1,863,617$ \\
Total RWA & 93,522 & 133,743 \\
Actual CAR \% & $14,735,426$ & $15,441,061$ \\
\end{tabular}


(ICAAP); through the modification of capital ratios, enhancement of banking financial stability, to adjust any gap that arises between the current and the targeted risk levels of the banks' capital structures, and by turn affects the sustainability, and the growth standards of banks positively.

The research study had focused on the ICAAP capability in terms of capital planning assessments in light of prevailing markets and economic conditions, effects on banks, corrective action plans needed, if any, as experienced with the sample study banks, and plans for facing the fall in capital adequacy levels, for example due to currency devaluation similar to the scenario of the EGP free float. Moreover, the research study has also highlighted banks' needs for reaching adequate risk management structures to ensure the sound management of financial and operational risks, by turn, to ease up the ICAAP process, findings, effective capital planning and effective decisioning; as a main subject towards the banking system stability and the worldwide economy's sustainable solidness.

Considering the mixed and limited findings with regard to the evaluation of the relationship between the Banking System Stability and the Internal Capital Adequacy Assessment Process-ICAAP; there was an increasing and considerable need for a comprehensive research study to present empirical robust results in order to provide an evidence in support of the significant relationship between the banking system stability and the Internal Capital Adequacy Assessment Process, in specific for the emerging markets, e.g. The Egyptian Banking system. The research study has focused on the period post the EGP devaluation that has started on November 3rd, 2016 which had witnessed a worsening trend for capital adequacy ratios within the Egyptian banks due to the Egyptian currency free float (CBE, 2016a), resulting in a decrease in common equity as being compared to RWA from 12.1\% on December 2015 to 9\% on December 2016 which represents a $26 \%$ decrease (CBE, 2017a); and the consequences on the Egyptian banking sector in terms of: The negative impact on the banks assets quality levels as a result of the deteriorating country economic factors like depreciating local currency, high inflation rates, and interest rates, in addition to the need for revisiting banks capital requirements and capital planning, cramming the causes of risks based on existing as well as future business plans, and strategies according to the new changing market and economic conditions, all besides assessing the capital needs, together with the corrective action plans in case of arising/forecasted crises and unfavorable economic conditions, such as capital falling below minimum capital requirement levels.

Although there were several limitations in this research study that in terms of the selected research study banks ( 5 banks) reasoned of the difficulty faced in terms of data access and confidentiality reasons across the banking sector, Egyptian banking sector in specific, especially for the data that shall be utilized under the internal capital adequacy assessment process (ICAAP), by turn the sample was only limited to those banks that are included in the selected sample; yet there is no significant difference between the selected Egyptian banks' structures and operations as being compared with the other Egyptian banks in terms of: 
Products bouquet, pricing, market penetration, functional structure, rely mainly on low cost domestic deposits and liquidity, rather than exposure to complex financial instruments, and facing the same market economic conditions during the under study period, i.e. the EGP free float effects on capital ratio levels, banking sector performance, which ends up with the close similarity between different Egyptian banks for the same mentioned factors for the study period.

All together, and for the selected sample banks, the ICAAP was utilized for reaching a sound capital management to identify, measure, and report all material risks, taking into account the banks' strategic focus and business plans, the process of internal controls, reviews and analysis included was showing clearly the ICAAP assessment, findings, and implemented corrective action plans following the Supervisory Review Process (SRP) for the Central Bank of Egypt (CBE), as well as Basel rules under pillar 2.

For all of these reasons, the research study has detailed how the ICAAP represented such an effective risk management tool that has turned to be obligatory to assess and quantify all risks that may materially impact banks capital levels or earnings proactively, and ensure banks stable capital adequacy levels, from a holistic perspective, over a medium and long term according to each and every bank's business plan and risk profiling criteria.

In simple terms, this research study had answered on the main question of the study which was: Does the ICAAP have a significant effect on the Banking System Stability? The answer is "Yes". Banks are required to manage their own particular detailed ICAAP, to show that they have executed techniques, systems, and processes to guarantee satisfactory capital resources, with due consideration regarding all material hazards and hold adequate funding to cover extra risks outside of those risks characterized under pillar I, and acting as a 360 degrees review tool for assessing and evaluating all banks risks and capital levels.

\section{Conflicts of Interest}

The author declares no conflicts of interest regarding the publication of this paper.

\section{References}

Admati, A. R., DeMarzo, P. M., Hellwig, M. F., \& Pfleiderer, P. C. (2013). Fallacies, Irrelevant Facts, and Myths in the Discussion of Capital Regulation: Why Bank Equity Is Not Socially Expensive, 2013. Stanford University Graduate School of Business.

Allen, F., Carletti, E., \& Marquez, R. (2014). Deposits and Bank Capital Structure.

Archarya, V., Engle, R., \& Pierret, D. (2014). Testing Macro Prudential Stress Tests: The Risk of Regulatory Risk Weights. Journal of Monetary Economics.

Banco de España (2011). Banco de España Supervisory Model. http://www.bde.es/f/webbde/COM/Supervision/funciones/Ficheros/en/Banco_de_Espa na_supervisory_model_clean.pdf

Banco de Espana, Executive Committee (2011). Guidelines on the Internal Capital Adequacy Assessment Process (ICAAP) at Credit Institutions, Madrid, Spain.

Bank Credit Loss Distribution Durrani, K. (2013). A Regulatory Examination of Provi- 
sioning, Capital Adequacy and Stress-Testing.

Bank of England (2013). The Internal Capital Adequacy Assessment Process (ICAAP) and the Supervisory Review and Evaluation Process (SREP), London, UK.

Basel Committee on Banking Supervision (1996). Amendment of the Capital Accord to Incorporate Market Risk. Basel: Bank for International Settlements.

Basel Committee on Banking Supervision (2000). Principles of the Management of Credit Risk. Basel: Bank for International Settlements.

Basel Committee on Banking Supervision (2006). A Global Regulatory Framework for More Resilient Banks and Banking Systems. Basel, Switzerland: Bank of International Settlements. http://www.bis.org/publ/bcbsca.htm http://www.bis.org/bcbs/basel3.htm

Basel Committee on Banking Supervision (2009). A Global Regulatory Framework for More Resilient Banks and Banking Systems. Basel, Switzerland: Bank of International Settlements. http://www.bis.org/publ/bcbsca.htm http://www.bis.org/bcbs/basel3.htm

Basel Committee on Banking Supervision (2010). A Global Regulatory Framework for More Resilient Banks and Banking Systems. Basel, Switzerland: Bank of International Settlements. http://www.bis.org/publ/bcbsca.htm http://www.bis.org/bcbs/basel3.htm

Basel Committee on Banking Supervision (2011a). A Global Regulatory Framework for More Resilient Banks and Banking Systems. Basel, Switzerland: Bank of International Settlements. http://www.bis.org/publ/bcbsca.htm http://www.bis.org/bcbs/basel3.htm

Basel Committee on Banking Supervision (2011b). Principles of the Sound Management of Operational Risk. Basel: Bank for International Settlements.

Basel Committee on Banking Supervision (2012). A Global Regulatory Framework for More Resilient Banks and Banking Systems. Basel, Switzerland: Bank of International Settlements. http://www.bis.org/publ/bcbsca.htm http://www.bis.org/bcbs/basel3.htm

Basel Committee on Banking Supervision (2014). A Global Regulatory Framework for More Resilient Banks and Banking Systems. Basel, Switzerland: Bank of International Settlements. http://www.bis.org/publ/bcbsca.htm http://www.bis.org/bcbs/basel3.htm

Basel Committee on Banking Supervision, Basel Committee Charter. Bank of International Settlements, Basel, Switzerland. https://www.bis.org/bcbs/charter.htm

Bauducco, S., Bulir, A., \& Cihak, M. (2008). Monetary Policy Rules with Financial Instability. Working Papers Czech National Bank.

Business Monitor International Financial Group (2016). Egypt Commercial Banking Report.

Calomiris, C. W., \& Kahn, C. M. (1991). The Role of Demandable Debt in Structuring Optimal Banking Arrangements. American Economic Review.

Caruana, J. (2007). Shifting Roles in Financial Globalization. IMF Survey.

Central Bank of Egypt (2008). Reform Banking Phases. Cairo: The Central Bank of Egypt. http://www.cbe.org.eg/en/BankingSupervision/Pages/ReformPhase1.aspx

Central Bank of Egypt (2009a). Annual Reports. http://www.cbe.org.eg/en/EconomicResearch/Publications/Pages/AnnualReport.aspx 
Central Bank of Egypt (2009b). Capital Tier 2 Components, Subordinated Loans and Deposits. Cairo: The Central Bank of Egypt

Central Bank of Egypt (2009c). Reform Banking Phases. Cairo: The Central Bank of Egypt. http://www.cbe.org.eg/en/BankingSupervision/Pages/ReformPhase1.aspx

Central Bank of Egypt (2012a). Annual Reports. http://www.cbe.org.eg/en/EconomicResearch/Publications/Pages/AnnualReport.aspx

Central Bank of Egypt (2016a). Annual Reports. http://www.cbe.org.eg/en/EconomicResearch/Publications/Pages/AnnualReport.aspx

Central Bank of Egypt (2016b). Internal Capital Adequacy Assessment Process. ICAAP Discussion Paper, Cairo: The Central Bank of Egypt.

Central Bank of Egypt (2016c). Local Currency Free Float. Cairo: The Central Bank of Egypt.

Central Bank of Egypt (2016d). The Monthly Statistical Bulletin. Cairo: The Central Bank of Egypt.

http://www.cbe.org.eg/en/EconomicResearch/Publications/Pages/MonthlyStatisticaclB ulletin.aspx

Central Bank of Egypt (2017a). Capital Tier 2 Components, Subordinated Loans and Deposits. Cairo: The Central Bank of Egypt.

Central Bank of Egypt (2017b). The Monthly Statistical Bulletin. Cairo: The Central Bank of Egypt.

http://www.cbe.org.eg/en/EconomicResearch/Publications/Pages/MonthlyStatisticaclB ulletin.aspx

Central Bank of Egypt CBE (2009d). Capital Requirements, Minimum Capital Requirements and Capital Conservation Buffers. Cairo: The Central Bank of Egypt.

Central Bank of Egypt CBE (2012b). Capital Requirements, Minimum Capital Requirements and Capital Conservation Buffers. Cairo: The Central Bank of Egypt.

Central Bank of Egypt CBE (2016e). Capital Requirements, Minimum Capital Requirements and Capital Conservation Buffers. Cairo: The Central Bank of Egypt.

Commercial International Bank, Egypt (2016). Annual Reports.

Commercial International Bank, Egypt (2017). Annual Reports.

Credit Agricole Bank, Egypt (2016-2017). Annual Reports.

Dinodia, P. (2014). SunGard, Ambit Risk \& Performance, ICAAP-The What, Why, and How.

Dudley, W. (2011). Bretton Woods Committee International Council Meeting, Washington DC. Financial Stability and Economic Growth. http://www.bis.org/review/r110927c.pdf

Durrani, K. (2013). Bank Credit Loss Distribution. A Regulatory Examination of Provisioning, Capital Adequacy and Stress-Testing.

https://ses.library.usyd.edu.au/bitstream/2123/9404/1/durrani_kj_thesis\%20with\%20co pyright.pdf

Duygun, F. M., Shaban, M., \& Weyman-Jones, T. (2012). Turkish Banking Recapitalization and the Financial Crisis: An Efficiency and Productivity Analysis. Emerging Markets Finance \& Trade, 48, 76-90. https://doi.org/10.2753/REE1540-496X4806S506

Edgar, M. (2005). Pillar 2 in Basel II-Supervisory Implications and Implementation in Germany. https://www.bis.org/review/r050426i.pdf

Financial Standard Board FSB (2009). Improving Financial Regulation. Report of the Fi- 
nancial Stability Board to G20 Leaders.

Flannery, M. J., Kwan, S. H., \& Nimalendran, M. (2010). The 2007-09 Financial Crisis and Bank Opaqueness. Working Paper Series, Federal Reserve Bank of San Francisco.

Garry, S. (2004). Defining Financial Stability, International Monetary Fund (IMF). https://www.imf.org/external/pubs/ft/wp/2004/wp04187.pdf

Hakkio, C., \& Keeton, W. (2009). Financial Stress, What Is It, How Can It Be Measured, and Why Does It Matter? Economic Review-Federal Reserve Bank of Kansas City, Second Quarter.

HSBC Bank plc (2008-2017). Annual Reports.

Ingo, F., Michael, G., \& Mosser, P. (2001). An International Survey on Stress Tests.

Justin, T. (2013). ICAAP-Internal Capital Adequacy Assessment Process, Monetary Authority of Singapore.

http://www.cafral.org.in/sfControl/content/DocumentFile/1031201330300PM_Session 1_ICAAP_and_SREP_Justin.pdf

Laeven, L., \& Valencia, F. (2010). Resolution of Banking Crises: The Good, the Bad, and the Ugly. International Monetary Fund Publications.

Lown, C., Morgan, D., \& Rohatgi, S. (2000). Listening to Loan Officers, the Impact of Commercial Credit Standards on Lending and Output. Economic Policy Review Federal Reserve Bank of New York.

Macropolis International Publishing Company (2015). Top Banks in Egypt. http://www.marcopolis.net/top-banks-in-egypt.htm

Mehran, H., \& Thakor, A. (2009). Bank Capital and Value in the Cross-Section. Federal Reserve Bank of New York Staff Reports, No. 390.

SAMA (2016). Annual Statistics Report, Oil Statistics.

SAMBA Financial Group, The Kingdom of Saudi Arabia (2008-2017). Annual Reports.

SAMBA Financial Group, The Kingdom of Saudi Arabia (2013). Risk Management Annual Report.

SAMBA Financial Group, The Kingdom of Saudi Arabia (2016). Basel III Disclosures.

Shri, L. (2005). Regulation and Risk Management-Implementing Basel II. https://www.bis.org/review/r050715g.pdf

Teixeira, J., Silva, F., Fernandes, A., \& Alves, A. (2013). Banks Capital, Regulation and the Financial Crisis.

The Federal Reserve Bank FRB (2008). Supervisory Guidance: Supervisory Review Process of Capital Adequacy (Pillar 2) Related to the Implementation of the Basel II Advanced Capital Framework.

The Federal Reserve Bank FRB (2015). Supervisory Guidance: Supervisory Review Process of Capital Adequacy (Pillar 2) Related to the Implementation of the Basel II Advanced Capital Framework.

The Federal Reserve Bank FRB (2016). Commercial Bank Examination Manual. Division of Banking Supervision and Regulation.

The Guardian (2013). Banks Still Too Clever for Regulators. http://www.theguardian.com/business/blog/2013/feb/26/banks-regulators-risk-measur ement-europe-eba

The Saudi Arabian Monetary Agency (SAMA) (2008). SAMA's Guideline Document on the Internal Capital Adequacy Assessment Process (ICAAP). 
The Saudi Arabian Monetary Agency (SAMA) (2011). SAMA's Guideline Document on the Internal Capital Adequacy Assessment Process (ICAAP).

The Union National Bank Egypt (2016-2017). Annual Reports.

Weber, R. (2014). A Theory for Deliberation-Oriented Stress Testing Regulation. Minnesota Law Review. 